\title{
Media Pembelajaran Online Untuk Mendukung Proses Belajar Pada Stebis Islam Darussalam
}

\author{
Tri Oktarina
}

\author{
Fakultas Ilmu Komputer, Universitas Bina Darma \\ E-Mail: trioktariana@binadarma.ac.id
}

\begin{abstract}
ABSTRAK
Penelitian ini dilakukan untuk mengembangkan sistem pembelajaran yang ada di STEBIS Islam Darussalam. STEBIS Islam Darussalam merupakan salah satu Perguruan Tinggi swasta yang ada Provinsi Sumatera Selatan. Sistem pembelajaran yang diterapkan sekarang ini berupa pertemuan tatap muka didalam kelas, dengan beberapa cara penyampaian materi antara lain persentasi, diskusi, dan tanya jawab secara langsung. Adapun media yang digunakan dalam pembelajaran saat ini buku fisik, proyektor, dan papan tulis. Kelemahan dari sistem ini, apabila ada mahasiswa yang kurang paham dengan materi atau ketinggalan materi akan sulit untuk mempelajari atau mengulang materi karena harus mencari sumber-sumber buku yang dijadikan rujukan materi. Mahasiswa yang ingin mempelajari kembali materi juga harus membawa materi dalam bentuk fisik, hal tersebut juga kurang efektif karena tidak mudah untuk dibawa kemana-mana. Solusi dari pemasalah tersebut, perlu adanya pengembangan media pembelajaran secara online berupa media pembelajaranonline. Media pembelajran online ini disajikan dalam bentuk buku digital.Tujuan dari penelitian ini untuk mempermudah mahasiswa dalam mempelajari dan mengulang materi, karena media pembelajaran tersebut dapat diakses secara online. Metode pengembangan sistem yang digunakan adalah metode waterfalldengan beberapa tahapanyaitucommunication, planning, modeling, construction, \& deployment. Hasil dari Penelitian ini berupa media pembelajaran online pada STEBIS Islam Darussalam.

Kata Kunci: pembelajaran online, STEBIS, waterfall
\end{abstract}

\begin{abstract}
This research was conducted to develop a learning system in STEBIS Islam Darussalam. STEBIS Islam Darussalam is one of the private universities in South Sumatra Province. The learning system that is currently implemented consists of face-to-face meetings in the classroom, with several ways of delivering material including presentations, discussions, and direct questioning. The media currently used in learning today are physical books, projectors, and blackboards. The weakness of this system, there are revisions of students who do not understand the material or material backward will be difficult to obtain or re-material must find sources of books that made reference material. Students who want to return the material must also bring the material in physical form, this is also less effective because it is not easy to carry anywhere. The solution of these speakers, the need for the development of online learning media is an online learning media. This online learning media is presented in the form of digital books. The purpose of this study is to facilitate students in learning and repeating material, because the learning media can be accessed online. The system development method used is the waterfall method with several developments namely communication, planning, modeling, construction, \& deployment. The results of this study are online learning media at STEBIS Islam Darussalam.
\end{abstract}

Keyword:online learning, STEBIS, waterfall

Author Korespondensi (Tri Oktarina)

Email : trioktariana@binadarma.ac.id 


\section{PENDAHULUAN}

Diera kemajuan industri 4.0 saat ini, teknologi informatika sudah merabah ke berbagai lingkungan salah satunya di lingkungan pendidikan. Setiap perguruan tinggi ingin menghasilkan lulusan yang berkualitas, oleh karena itu harus didukung dengan fasilitas secara maksimal. Sekarang masih ada perguruan tinggi yang belum memanfaatkan kemajuan teknologi informasi untuk mendukung fasilitas terutama fasilitas pembelajaran. Salah satu perguruan tinggi tersebut adalah STEBIS Islam Darussalam. Media pembelajaran dapat dipahami sebagai segala sesuatu yang dapat menyampaikan atau menyalurkan pesan dari sumber secara terencana, sehingga terjadi lingkungan belajar yang kondusif dimana penerimanya dapat melakukan proses belajar secara efisien dan efektif [1].

STEBIS Islam Darussalam merupakan Sekolah Tinggi Ilmu Ekonomi dan Bisnis yang berada di Desa Tugu Mulyo Kecamatan Lempuing Kabupaten Ogan Komering Ilir. Pada STEBIS Islam Darussalam sistem pembelajaran yang diterapkan sekarang ini, pertemuan tatap muka didalam kelas dengan beberapa cara dalam menyampaikan materi antara lain presentasi, diskusi, dan tanya jawab secara langsung. Adapun media yang digunakan dalam pembelajaran adalah buku fisik, proyektor, dan papan tulis. Kelemahan dari sistem ini, apabila ada mahasiswa yang kurang paham dengan materi dan ketinggalan materi akan sulit untuk mempelajari atau mengulang materi karena harus mencari sumber-sumber buku yang dijadikan rujukan materi. Mahasiswa yang ingin mempelajari kembali materi juga harus membawa materi dalam bentuk fisik, hal tersebut juga lumanya susah apabila karena tidak bisa dibawa kemana-mana.

Maka untuk mengatasi masalah di STEBIS Islam Darussalam perlu adanya pengembangan dan penambahan sistem pembelajaran berbasis teknologi informasi (online), untuk mempermudah mahasiswa dalam mempelajari dan mengulang materi. Kemudahan dari pengembangan dan penambahan adalah materi dapat dipelajari atau diulang kembali dimana tempatnya secara online. Penelitian ini menghasilkan media pembelajaran online pada STEBIS Islam Darussalam.
Penelitian terkait yang dijadikan rujukan untuk penelitian ini adalah:

1. Materi Digital Berbasis Web Mobile Menggunakan Model 4D [2],

2. Pengembangan Fitur Notifikasi E-Modul Pada Program Studi Manajemen Informatika [3],

3. Pengembangan Media Pembelajaran Berbasis Moodle pada Mata Kuliah Fisika Dasar[4],

4. Cara Membuat Media Pembelajaran Online Menggunakan Edmodo[5],

5. Pengembangan Blog Sebagai Media Pembelajaran Matematika[6],

6. Keefektifan e-learning Sebagai Media Pembelajaran (studi evaluasi model pembelajaran e-learning SMK Telkom Sandhy Putra Purwokerto)[7].

\section{METODOLOGI}

\subsection{Teknik Pengumpulan Data}

Teknik pengumpulan data merupakan langkah yang paling strategis dalam melakukan penelitian, karena tujuan dari penelitian adalah mendapatkan data untuk menghasilkan informasi yang berguna [8]. Metode penelitian yaitu cara ilmiah dalam mengumpulkan data untuk tujuan dan kegunaan tertentu [9].

Metode pengumpulan data yang digunakan dalam penelitian ini yaitu teknik observasi, teknik interview, dan teknik dokumentasi.

2.1.1. Teknik observasi [10]

Observasi merupakan penelitian yang dilakukan secara langsung dengan melihat proses pembelajaran yang ada pada STEBIS Islam Darussalam.

2.1.2. Teknik interview [11]

Interview merupakan wawacara yang dilakukan terhadap dosen STEBIS Islam Darussalam. Inti dari wawacara tersebut berupa bagaimana proses pembelajaran yang ada di STEBIS Islam Darussalam, media pembelajaran apa saja yang digunakan di STEBIS Islam Darussalam, apa saja yang menjadi kendala dalam proses belajar mengajar di STEBIS Islam Darussalam, dan fasilitas apa saja yang digunakan untuk mendukung proses belajar mengajar di STEBIS Islam Darussalam.

2.1.3. Teknik dokumentasi [12]

Dokumentasi merupakan pengumpulan dokumen-dokumen yang diperlukan dalam penelitian. Apapun dokumen yang di-perlukan 
untuk penelitian dari STEBIS Islam matakuliah.

Darussalam yaitu RPS, silabus, dan modul

\subsection{Metode Waterfall}

Menurut [13], model waterfall adalah model

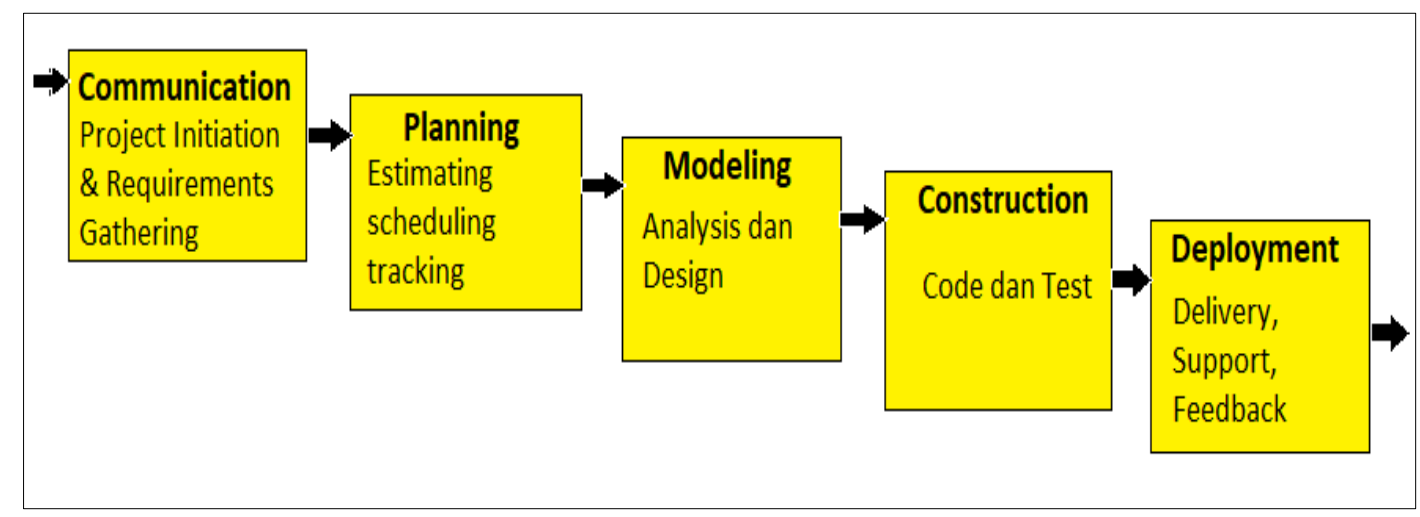

Gambar 1. Metode waterfall

klasik yang bersifat sistematis, berurutan dalam membangun software. Nama model ini sebenarnya adalah "Linear Sequential Model". Model ini sering disebut juga dengan "classic life cycle" atau metode waterfall.

Adapun metode pengembangan aplikasi yang digunakan untuk membangun media pembelajaran online pada STEBIS Islam Darussalam adalah metode waterfall (Gambar 1) dengan fase-fase sebagai berikut, Perseman 2015:

\subsubsection{Communication (Project Initiation \& Requirements Gathering).}

Pada tahap ini peneliti sebelum memulai pekerjaan yang bersifat teknis, sangat diperlukan adanya komunikasi dengan customer demi memahami dan mencapai tujuan yang ingin dicapai. Hasil dari komunikasi tersebut adalah inisialisasi proyek, seperti menganalisis permasalahan yang dihadapi dan mengumpulkan data-data yang diperlukan, serta membantu mendefinisikan fitur dan fungsi software. Pengumpulan data-data tambahan bisa juga diambil dari jurnal, artikel, dan internet.

\subsubsection{Planning (Estimating, Scheduling, Tracking)}

Tahap berikutnya adalah tahapan perencanaan yang menjelaskan tentang estimasi tugas-tugas teknis yang akan dilakukan, resikoresiko yang dapat terjadi, sumber daya yang diperlukan dalam mem-buat sistem, produk kerja yang ingin dihasilkan, penjadwalan kerja yang akan dilaksanakan, dan tracking dalam proses pengerjaan sistem.

\subsubsection{Modeling (Analysis \& Design)}

Tahapan ini adalah tahap perancangan dan permodelan arsitektur sistem yang berfokus pada perancangan struktur data, arsitektur software, tampilan interface, dan algoritma program. Tujuannya untuk lebih memahami gambaran besar dari apa yang akan dikerja-kan.

\subsubsection{Construction (Code \& Test)}

Tahapan Construction ini merupakan proses penerjemahan bentuk desain menjadi kode atau bentuk/bahasa yang dapat dibaca oleh mesin. Setelah pengkodean selesai, dilakukan pengujian terhadap sistem dan juga kode yang sudah dibuat. Tujuannya untuk menemukan kesalahan yang mungkin terjadi untuk nantinya diperbaiki.

\subsubsection{Deployment (Delivery, Support, Feedback)}

Tahapan Deployment merupakan tahapan implementasi software ke customer, pe-meliharaan software secara berkala, perbaikan software, evaluasi software, dan pengembangan software berdasarkan umpan balik yang diberikan agar sistem dapat tetap berjalan dan berkembang sesuai dengan fungsinya.

\section{HASIL DAN PEMBAHASAN}

\subsection{Perancangan Proses}

Pada perancangan proses media pembelajaran online pada STEBIS Islam Darussalam penelitian menggunakan desain usecase diagram 
dan flowchart diagram.

Pada perancangan usecase diagram menjelaskan bagaimana suatu actor (admin, dosen, dan mahasiswa) berintraksi menggunakan sistem. Seorang admin mempunya hak penuh untuk mengakses semua halaman sistem antara lain login, upload media pembelajaran, melihat isi media pembelajaran, melakukan proses edit dan delete media pembelajaran dan keluar. Seorang dosen mempunyai akses untuk beberapa menu antara lain login, mengupload media pembelajaran, melihat isi media pembelajaran secara online, dan keluar, sedangkan mahasiswa mempunyai hak untuk login, dan mempelajari materi. Usecase media pem- belajaran online dapat dilihat pada Gambar 2.

Sedangkan flowchart menerangkan jalannya sistem dari masuk ke sistem sampai keluar dari sistem. Adapun proses flowchart tersebut mengakses sistem kemudian mengupload media pembelajaran, selanjutnya sistem memeriksa apakah data sesuai atau tidak sesuai, apabila tidak sistem akan menolak dan apabila benar sistem akan memproses menuju ke penyimpanan database, selanjutnya media pembelajaran dapat diakses dan dipelajari. Flowchart media pem-belajaran online dapat dilihat pada Gambar 3 .

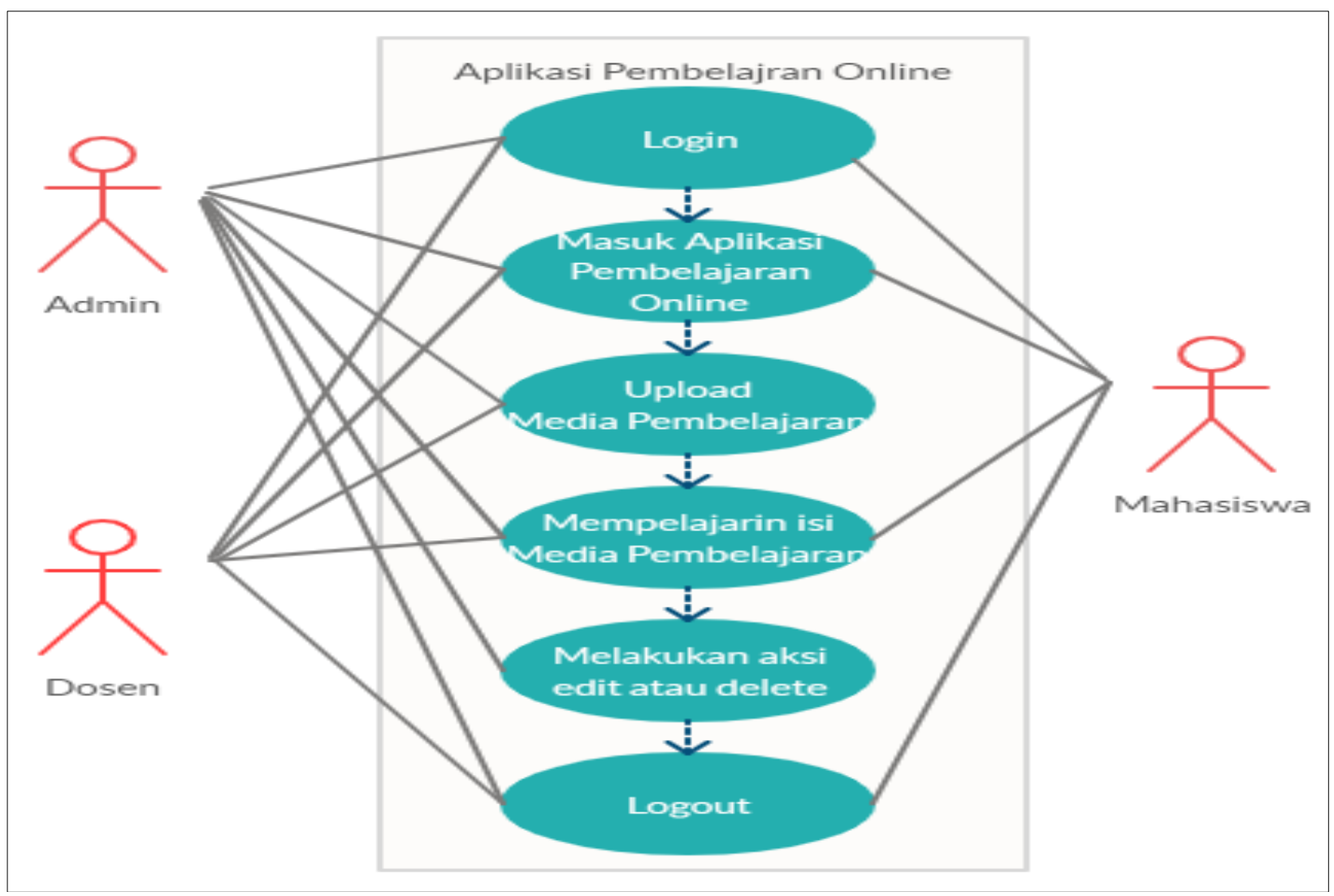

Gambar 2. Usecase desain proses aplikasi media pembelajaran online 


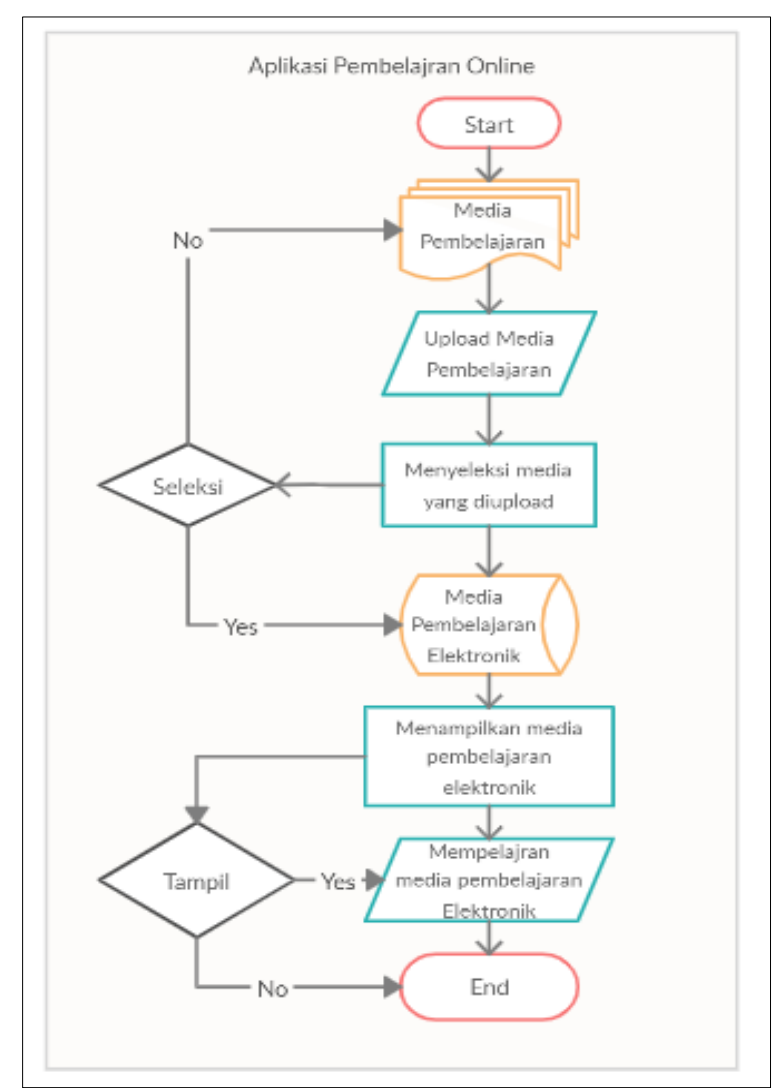

Gambar 3. Flowchart desain proses aplikasi media pembelajaran online

\subsection{Tampilan Media Pembelajaran Online}

Tampilan media pembelajaran online dihasilkan dari proses analisis, desain, dan pengkodean. Media pembelajarn online ini dibangun untuk meningkatkan kemampuan hasil belajar mahasiswa. Adapun tampilan yang dihasilkan adalah sebagai berikut:

\subsubsection{Tampilan Login.}

Tampilan ini merupakan tampilan awal pada media pembelajaran online yang diakses melalui website. Login ini merupakan keamanan dalam mengakses media pembelajaran online, untuk masuk ke sistem dengan menggunakan username dan password yang sudah terdaftar. Username yang mempunya hak akses adalah admin, dosen, dan mahasiswa, sesuai dengan hak aksesnya masing-masing. Adapun halaman login dapat dilihat pada Gambar 4. 


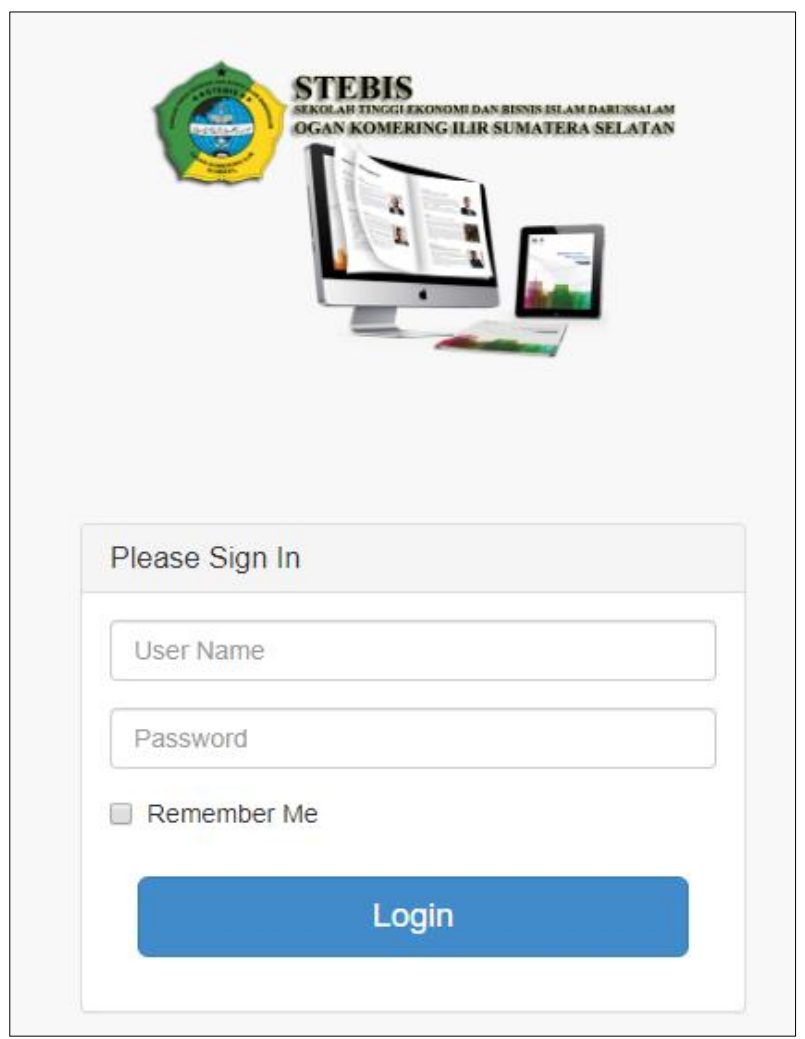

Gambar 4. Login media pembelajaran online

\subsubsection{Home}

Tampilan ini tampil ketika user behasil melakukan login. Setiap user mempuyai tampilan home masing-masing. Pada homeadmin terdapat beberapa menu antara lain menu program studi yang di dalam terdapat sub-sub menu antara lain menu jurusan ekonomi dan jurusan manajemen. Pada sub-sub menu tersebut berisi bahan ajar elektronik yang dapat digunakan dalam proses belajar mahasiswa sesuai dengan jurusan masing-masing. Tampilan home media pembelajaran online STEBIS Islam Darussalam dapat dilihat pada Gambar 5.

\subsubsection{Daftar media pembelajaran online}

Daftar media pembelajaran online, merupa-kan kumpulan dari media pembelajaran online. Interface daftar media pembelajaran online admin dapat dilihat pada Gambar 6, dan sedangkan interface daftar media pembelajaran online mahasiswa dapat dilihat pada Gambar 7.
Pada interface daftar media pembelajaran online pada admin dan dosen terdapat fasilitas add data yang digunakan untuk menambah media pembelajaran online. Tampilan add media pembelajran online dapat dilihat pada Gambar 8. Berbeda dengan interface daftar modul digital mahasiswa tidak mempunyai fasilitas add data, hanya daftar dari media pembelajaran online.

\subsubsection{Detail media pembelajaran online}

Detail media pembelajaran online, merupa-kan penjelasan detail dari media pembelajaran online. Interface detail media pembelajaran online pada semua user terdiri dari judul media pembelajaran online, tanggal upload media pembelaajran online, diskripsi media pembelajaran online, capaian matakuliah, pokok bahasan, dan referensi. Detail media pembelajaran online dapat dilihat pada Gambar 9. 


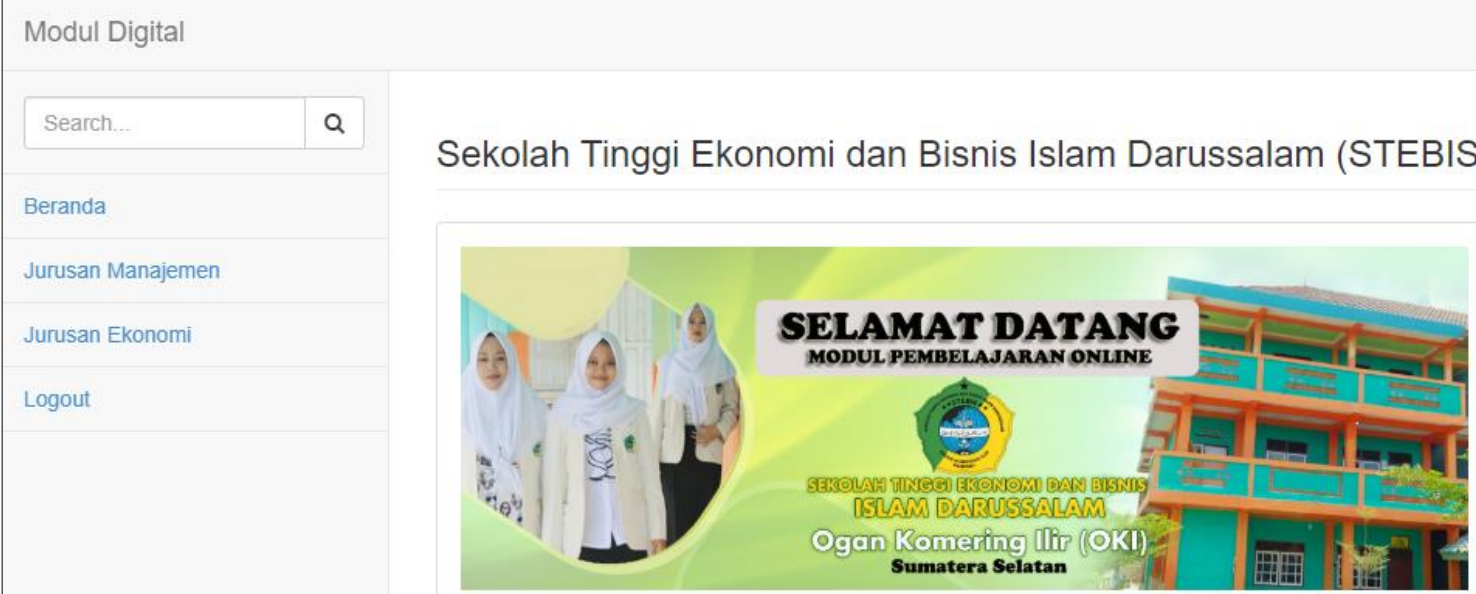

Gambar 5. Home media pembelajaran online

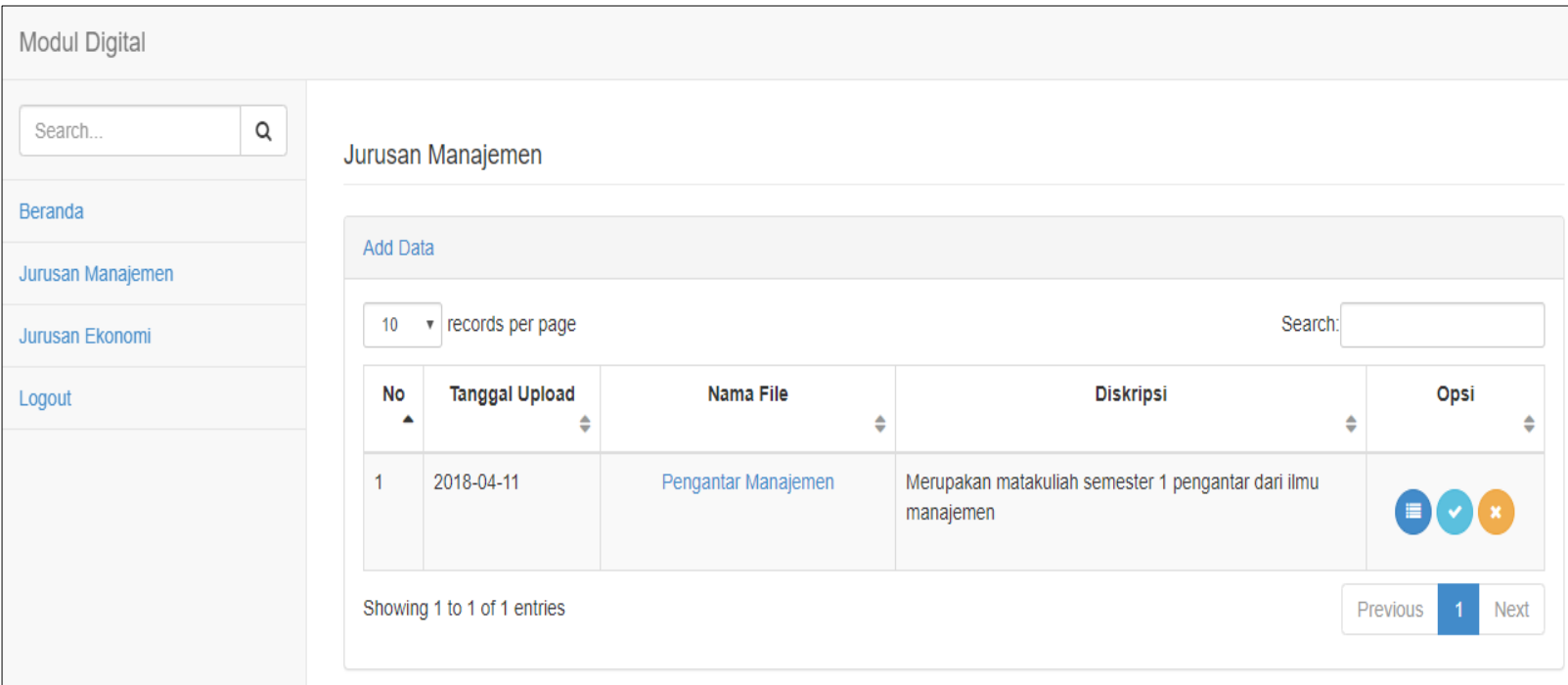

Gambar 6. Daftar media pembelajaran online pada admin 


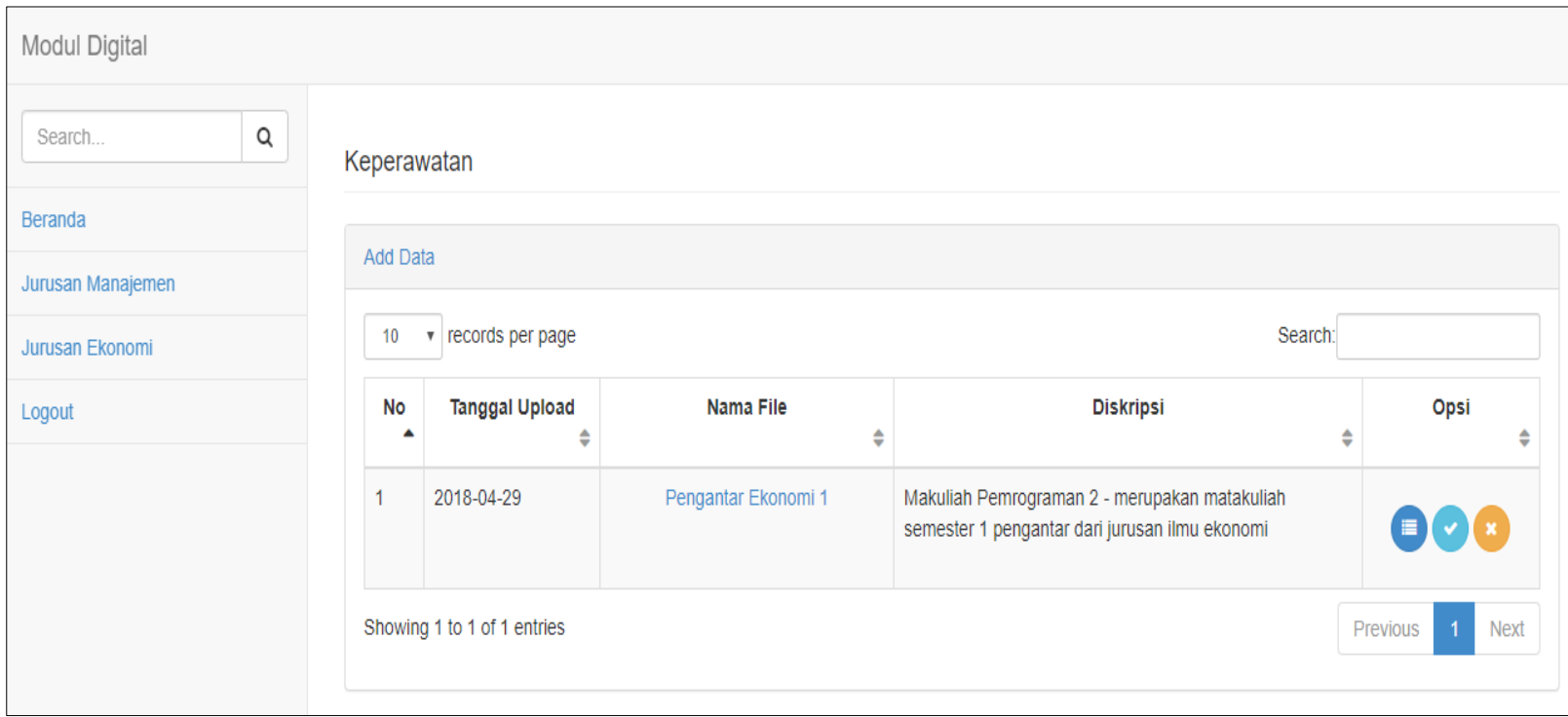

Gambar 7. Daftar media pembelajaran online pada Mahasiswa

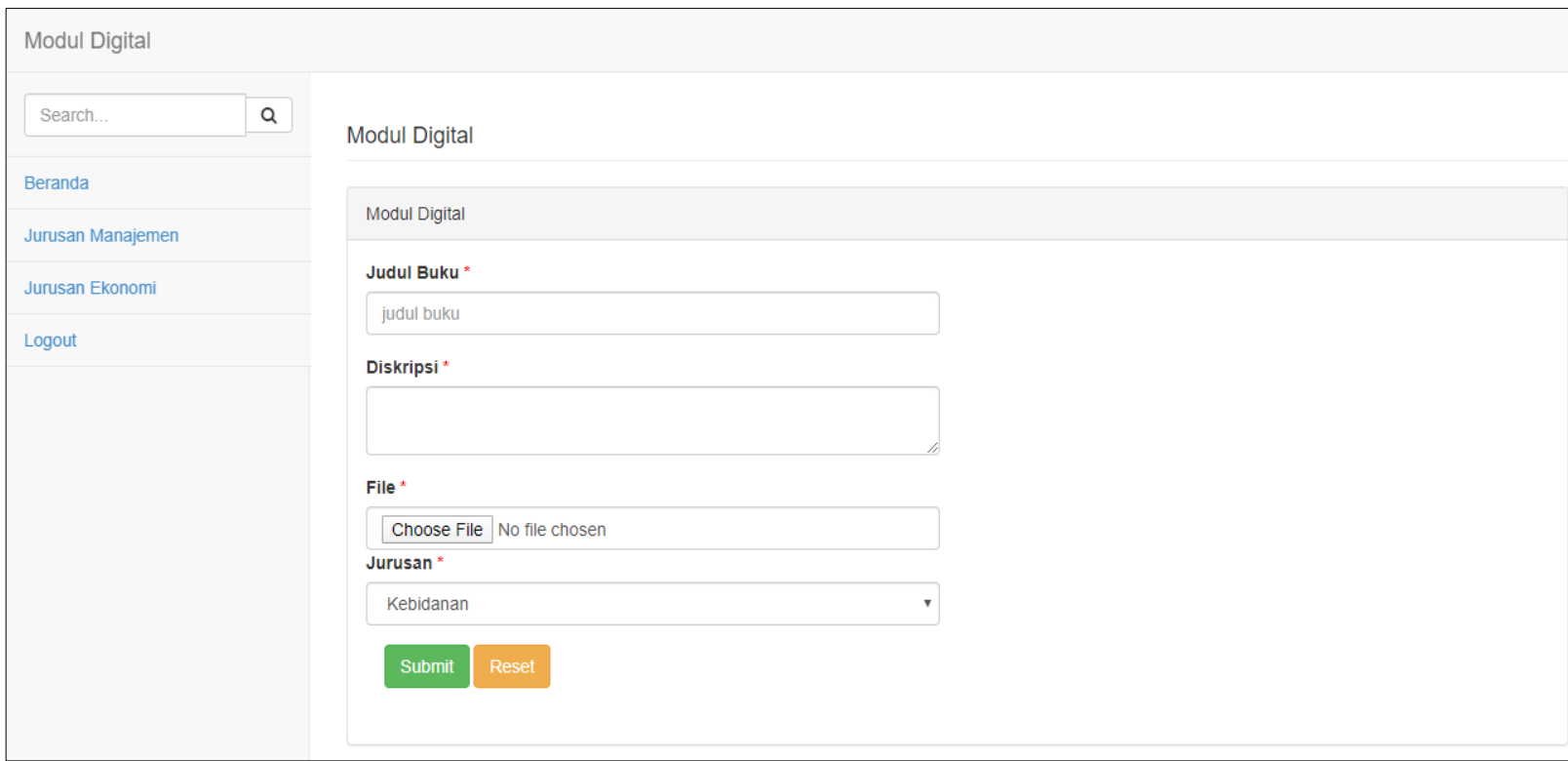

Gambar 8. Add media pembelajaran online pada Mahasiswa 


\begin{tabular}{|c|c|c|}
\hline \multicolumn{3}{|l|}{ Modul Digital } \\
\hline Search... & $Q$ & Detail Modul Digital \\
\hline \multicolumn{2}{|l|}{ Beranda } & \\
\hline \multicolumn{2}{|l|}{ Jurusan Manajemen } & Tanggal Upload \\
\hline \multicolumn{2}{|l|}{ Jurusan Ekonomi } & $2018-04-11$ \\
\hline \multicolumn{2}{|l|}{ Logout } & Judul Buku/Nama Matakuliah \\
\hline & & Pengantar Manajemen \\
\hline & & Diskripsi \\
\hline & & Merupakan matakuliah semester 1 pengantar dari ilmu manajemen \\
\hline
\end{tabular}

Gambar 9. Rincian media pembelajaran online

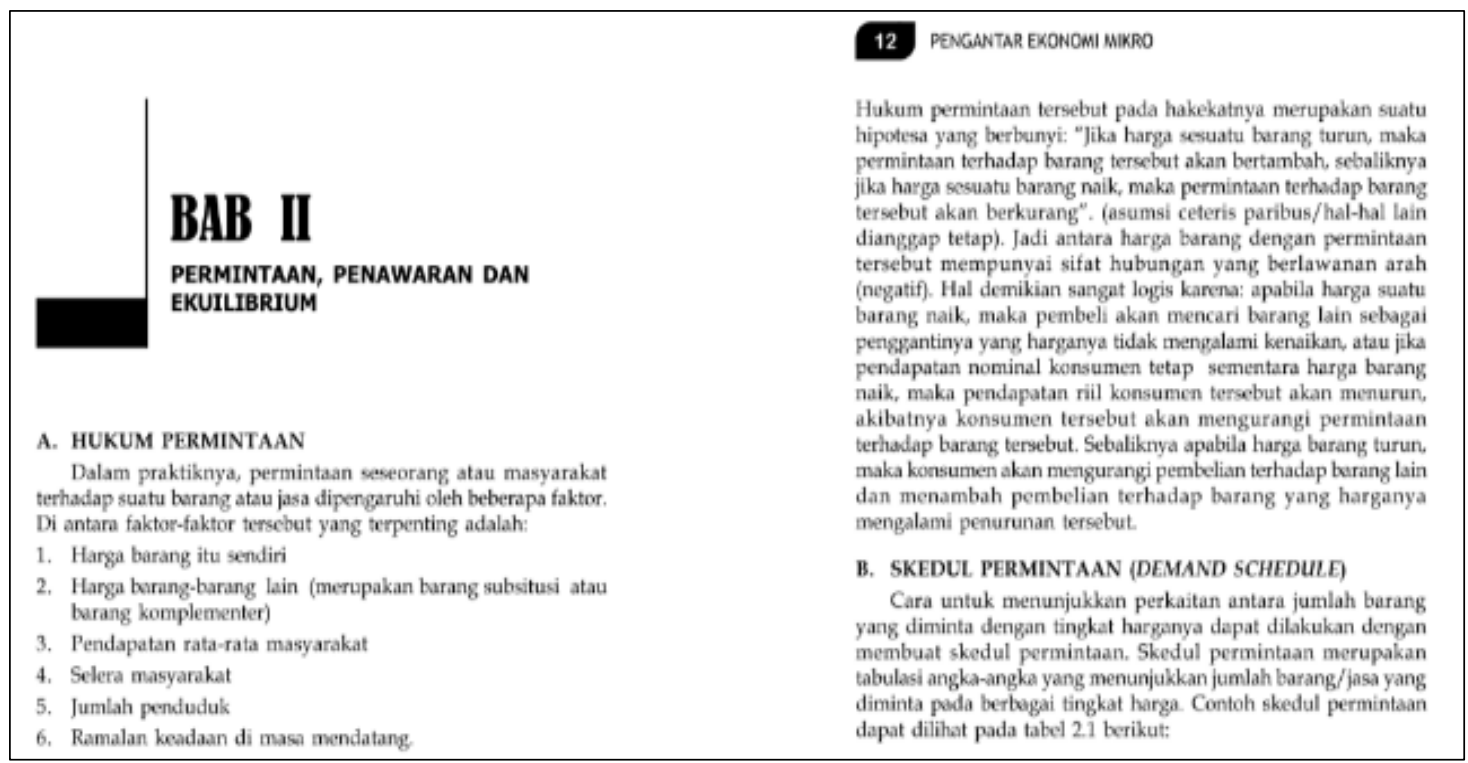

Gambar 10. Media pembelajaran online

\subsubsection{View media pembelajaran online} merupakan tampilan isi media pembelajaran online yang dibuka dan dapat dipelajari menggunakan suatu aplikasi melalui komputer berbasis web. tampilan view media pembelajaran online dapat dilihat pada gambar 10.

\subsubsection{Testing Aplikassi Media Pembelajaran Online}

Pengujian interface Media pembelajaran online berbasis web pada STEBIS Islam Darussalam menggunkan blackbox dengan hasil sebagai berikut:

1. Interface Login: halaman login tampil pertama kali ketika aplikasi media pembelajaran online baru diakses, kesimpulan hasil pengujian diterima (tidak error).

2. Interface home: merupakan halaman utama yang muncul ketika user berhasil melaukan login, user terdiri dari tiga user (admin, dosen, dan mahasiswa), kesimpulan hasil pengujian diterima (tidak error).

3. Interface media pembelajaran online: merupakan tampilan daftar dari semua modul digital berdasarkan program studi masing-masing, kesimpulan hasil pengujian diterima (tidak error).

4. Interface detail media pembelajaran online: merupakan tampilan penjelasan dari isi modul digital secara garis besar), kesimpulan hasil pengujian diterima (tidak error). 
5. Interface view media pembelajaran online: merupakan tampilan isi dari buku digital yang dapat dibuka dan dipelajari, kesimpulan hasil pengujian diterima (tidak error).

6. Interface add data: merupakan tampilan halaman yang berfungsi untuk menginputkan media pembelajaran online ke aplikasi media pembelajaran online berbasis web, kesimpulan hasil pengujian diterima (tidak error).

\section{SIMPULAN DAN SARAN}

Penelitian ini adalah media pembelajaran online berbasis web pada STEBIS Islam Darussalam untuk mendukung dalam proses belajar mengajar. Pada setiap media pembelajaran online terdapat penjelasan tentang diskripsi, capaian matakuliah, pokok bahasan dan referensi sehingga mahasiswa mengetahui secara garis besar isi media pembelajaran online. Media pembelajaran online ini dikembangkan untuk mempermudah dosen dalam menyampaikan materi dan mempermudah mahasiswa dalam mempelajari materi setiap matakuliah. Pada penelitian selanjutnya agar lebih dikembangkan ke arah aplikasi Android.

\section{REFERENSI}

[1] R. Asyhar, "Kreatif Mengembangkan Media Pembelajaran." Jakarta: Referensi Jakarta, 2012.

[2] I. Solikin and R. Amalia, "Materi Digital Berbasis Web Mobile Menggunakan Model 4D," Sist. J. Sist. Inf., vol. 8, no. 3, pp. 321-328, 2019.

[3] I. Solikin, "Pengembangan Fitur Notifikasi E-Modul Pada Program Studi Manajemen Informatika," Simetris J. Tek. Mesin, Elektro dan Ilmu Komput., vol. 10, no. 1, pp. 189-196, 2019.

[4] L. Herayanti, M. Fuaddunnazmi, and H. Habibi, "Pengembangan Media Pembelajaran Berbasis Moodle Pada Mata Kuliah Fisika Dasar," J. Pendidik. Fis. dan Teknol., vol. 1, no. 3, pp. 205209, 2017.

[5] N. Putranti, "Cara Membuat Media Pembelajaran Online Menggunakan Edmodo," J. Pendidik. Inform. dan Sains, vol. 2, no. 2, pp. 139-147, 2016.
Putra, and M. Syazali, "Pengembangan Blog Sebagai Media Pembelajaran Matematika," Al-Jabar J. Pendidik. Mat., vol. 8, no. 2, pp. 197-203, 2017.

[7] N. S. Hanum, "Keefetifan E-Learning Sebagai Media Pembelajaran (Studi Evaluasi Model Pembelajaran ELearning SMK Telkom Sandhy Putra Purwokerto)," J. Pendidik. Vokasi, vol. 3, no. 1, 2013.

[8] P. D. Sugiyono, "Metode Penelitian Kuantitatif dan Kualitatif dan R\&D," Bandung Alf., 2008.

[9] M. P. K. Sugiyono, "Cara Mudah Menyusun: Skripsi." Tesis dan Disertasi, Bandung: Alfabeta, 2014.

[10] H. Hasanah, "Teknik-Teknik Observasi (Sebuah Alternatif Metode Pengumpulan Data Kualitatif Ilmu-Ilmu Sosial)," AtTaqaddum, vol. 8, no. 1, pp. 21-46, 2017.

[11] H. Herdiansyah, "Wawancara, Observasi, Dan Focus Groups: Sebagai Instrumen Penggalian Data Kualitatif," Jakarta PT. Raja Graf. Persada, 2013.

[12] I. Gunawan, "Metode Penelitian Kualitatif," Jakarta Bumi Aksara, 2013.

[13] A. Pressman, "How Fitbit's Outsmarting Apple, At Least So Far.” 2015.

[6] A. A. Nugroho, R. W. Y. Putra, F. G. 